\title{
Effects Of Social Networking Sites (SNSs) On Hyper Media Computer Mediated Environments (HCMEs)
}

\author{
Yoon C. Cho, KDI School of Public Policy and Management, Korea
}

\begin{abstract}
Social Networking Sites (SNSs) are known as tools to interact and build relationships between users/customers in Hyper Media Computer Mediated Environments (HCMEs). This study explored how social networking sites play a significant role in communication between users. While numerous researchers examined the effectiveness of social networking websites, few studies investigated which factors affected customers' attitudes and behavior toward social networking sites. In this paper, the authors investigated what factors affected overall attitudes toward social networking sites and user satisfaction. This study found that users' attitudes toward social networking sites significantly affected their e-satisfaction. The findings of the study will contribute to the development of the satisfaction theories by applying them to users' attitudes toward social networking systems. Further, the study provides implications and offers suggestions to ebusinesses dealing with social networking systems.
\end{abstract}

Keywords: Social Networking System, Computer Mediated Communication, Usability and Technology Acceptance and User Satisfaction.

\section{Introduction}

ith the rapidly increasing adjustment of online communication system, users' attitudes and behavior toward web system have been varied and changed dramatically. Web usage changed from the use of simple email systems to advanced "my own space sites." This stream continued as users' expectations and expected satisfaction increased. Therefore, in this paper, the authors explore what factors affect user attitudes and satisfaction, particularly toward the Social Networking Sites (SNSs). In order to meet users' high levels of expectation in the online spaces, why they created "My Own Spaces" sites was widely investigated. According to Kimbal and Rheingold (2007), social networks grew from the personal interactions of human beings over time, as well as from the technological infrastructure that connected those humans in online environments. Social networking sites also enabled individuals to meet self-presentational and social goals (Boyd \& Ellison 2007). Hemp (2006) mentioned that, if the site provided "avatar-based services," which identified you, your lifestyle, and/or others, it was the virtual world of Second Life.

The previous study of Garton, Haythornthwaite, and Wellman (1997) addressed that the role of online communities (a.k.a., Social Networking Sites: SNSs) was to enhance self-esteem and increase relationships. This study addressed the effects of such Social Networking Sites (SNS), known as sites that allowed online users to develop their own web pages for the purpose of connecting people to enhance interactions and build relationships. Well-known Social Networking Sites (SNS), such as Cyworld.com, MySpace.com, Facebook.com, YouTube.com, and Bolt.com, captured the public's attention and attracted millions of users (Boyd \& Ellison 2007) by setting up social relationships, such as friendship, co-working or information exchange (Garton, Haythornthwaite, \& Wellman 1997). MySpace.com (51, 441 million users in May 2006), Facebook.com (14,069 million in May 2006), and YouTube.com (12,669 million in May 2006) continued to attract visitors (Comscore Media Metrix). Those sites offered differentiated services by enhancing usability and considering more pleasurable factors to maximize user satisfaction. Popular sites (in terms of user count) were provided to target specific populations, such as: 
MySpace.com, Netlog.com (formerly known as Facebox), hi5.com, and Friendster.com targeted to the general public; Classmates.com, Facebook.com, and Bebo.com targeted to or starting to target for schools and colleges; other sites, such as Cyworld.co.kr (targeted to young south Koreans), Skyblog.com (targeted to French, French Polynesian, etc.), and LunarStorm.com (targeted to the Swedish) targeted users in specific countries, but opened to users in other countries; and other sites, such as Sermo.com, targeted professionals, such as physicians (www.en.wikepedia.org).

Based on the consideration above, this study explored users' attitudes toward social networking sites, which encouraged social interaction by emphasizing connections through shared interests (Dwyer 2007). While numerous researchers examined the effectiveness of e-businesses, not many studies investigated factors that affect the effectiveness of social networking systems. Therefore, in this study, the authors investigated what factors affected overall attitudes toward social networking systems and user satisfaction. The purpose of this study was to explore: 1) factors affecting online users' attitudes toward social networking system; and 2) how overall attitudes toward social networking system affected user satisfaction. Previous studies noted various factors that might influence user attitudes toward social networking sites. News from Business Week (www.businesweek.com) stated that by enhancing functionality and providing an entertainment factor, social networking websites were more than just another website, but those are the nexus of pretty much everything those do. In order to examine such phenomena, this study applied various theories and models, such as the Technology Acceptance Model (TAM; Davis 1989a and b).

\section{Hypotheses Development}

Various studies have investigated impacts of Social Networking Sites. This study defined Social Networking Sites (SNSs) as involving a set of systems that support interwoven relationships (Mohammed et al. 2004) in online environments, such as email, instant messenger and community systems. According to Hanson (2000), online communities, which include Social Networking Sites, played a significant role in magnifying commentator views of the role, impact and consequence (Hanson 2000). Based on the study of Hagel and Armstrong (1997), a vision of the impact of online communities was described as the rise of virtual communities in online networks setting in motion an unprecedented shift in power from vendors of goods and services to the customers that buy them. According to Garton, Haythornthwaite, and Wellman (1997), a social network was a set of people (or organizations or other social entities) connected by a set of social relationships, such as friendship, co-working or information exchange. Further, online communities combined important features, such as Internet communication tools, rules that defined community membership, collaborative production of material by members and repeated use by members (Hagel \& Armstrong 1997). Thus, virtual gathering places deliver increasing value to customers. In particular, this value led to loyalty, customer involvement, rapid growth, and high profits (Hagel \& Armstrong 1997). Further, social network analysts sought to describe networks of relations as fully as possible, tease out the prominent patterns in such networks, trace the flow of information through them, and discover what effects those relations and networks had on people and organizations (Garton, Haythornthwaite, \& Wellman 1997).

A previous study by Hoffman, Novak, and Chatterjee (1995) stated that interactivity have contributed to the rapid diffusion of the Web as a commercial medium in many years. Authors stressed that social networking sites relied heavily on "customer or user interactions" in a Hyper Media Computer Mediated Environments (HCMEs; Hoffman, Novak, \& Chatterjee 1995) by significantly applying characteristics of 2Is (Interactivity and Individualization). Another study (Garton, Haythornthwaite, \& Wellman 1997) addressed how CMC affected the structure and functioning of social systems and how social structures affected the way CMC was used. This study posited that CMC played a significant role, particularly when customers were involved in social networking sites. As shown in Figure 1, CMC plays a role as intermediary if customers have virtual experience via telepresence in the market-space (Figure 1). Compared to physical or online markets with limited interaction (a \& b), SNSs are an appropriate example applied to the advanced role of $\mathrm{CMC}$ with unlimited interactivity (c). 


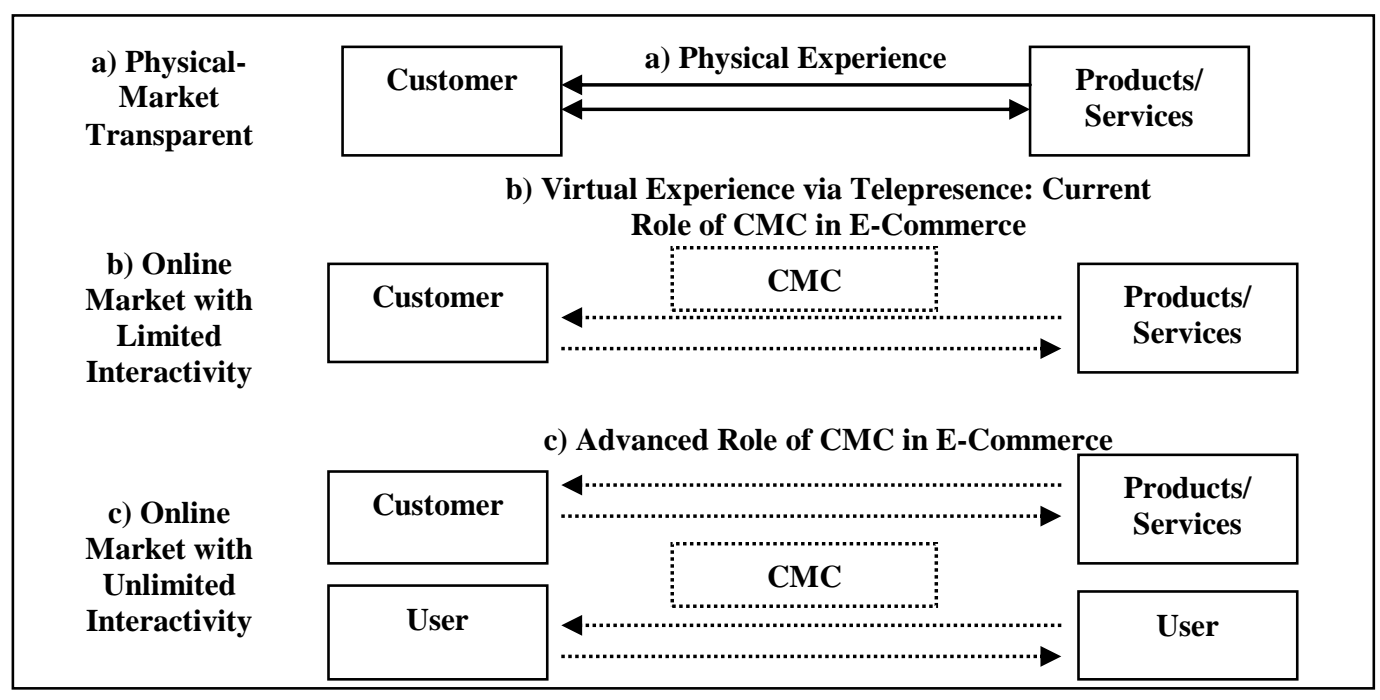

Figure 1: The Evolving Role of CMC in E-Commerce

Uses and gratification theory (Herzog 1944; McGuire1974; Luo 2002) was applied in this study to explain users' attitudes toward social networking sites and user satisfaction. The present study was also supported by other theories: one proposed by Ajzen and Fishbein (1980), often used in behavioral research, and another called the Theory of Reasoned Action (TRA), which suggested that individuals' performance of a given behavior was primarily determined by their intention to perform that behavior. This study adopted the Technology Acceptance Model (TAM), proposed by Davis (1989a and b), to explain specific behavior from electronic commerce. This study extended the TAM model by suggesting and finding factors that affect ease of use and usefulness. The proposed model for this study, as shown in Figure 2, was determined by the different factors that aroused the perceived ease of use and usefulness. In this study, perceived usefulness and ease of use were considered predictors to investigate the external variables that affected users' attitudes toward social networking sites.

Perceived usefulness (U) and perceived ease of use (EOU) were frequently used to measure users' attitudes toward websites and technology acceptance. Based on a definition by Davis (1989 a and b), perceived usefulness was "the degree to which a person believes that using a particular system would enhance his or her job performance." Davis (1989 a and b) also described perceived ease of use as "the degree to which a person believes that using a particular system would be free of effort." In this study, perceived usefulness and ease of use were considered predictors to investigate the external variables that affected users' acceptance of social networking sites. Attitudes toward a website were often considered a variable to measure the effectiveness of websites, systems or advertising (e.g., Zhou 2002; Chen \& Wells 1999). Attitudes toward a site were discussed to measure the ease of building a relationship with a business, website loyalty, e-satisfaction with the site or service provided by the business, length of time to stay on a website, or a comparison analysis between or among the sites (Chen \& Wells 1999; Schubert \& Selz 1999; Cho et al. 2002). This study proposed a modified model considering suggested factors that might affect attitudes toward social networking sites (Figure 2).

Hypothesis 1a: As perceived ease of use (EOU) of social networking sites increases, the users' overall satisfaction toward social networking sites will increase.

Hypothesis 1b: As perceived usefulness (U) of social networking sites increases, the users' overall satisfaction toward social networking sites will increase. 


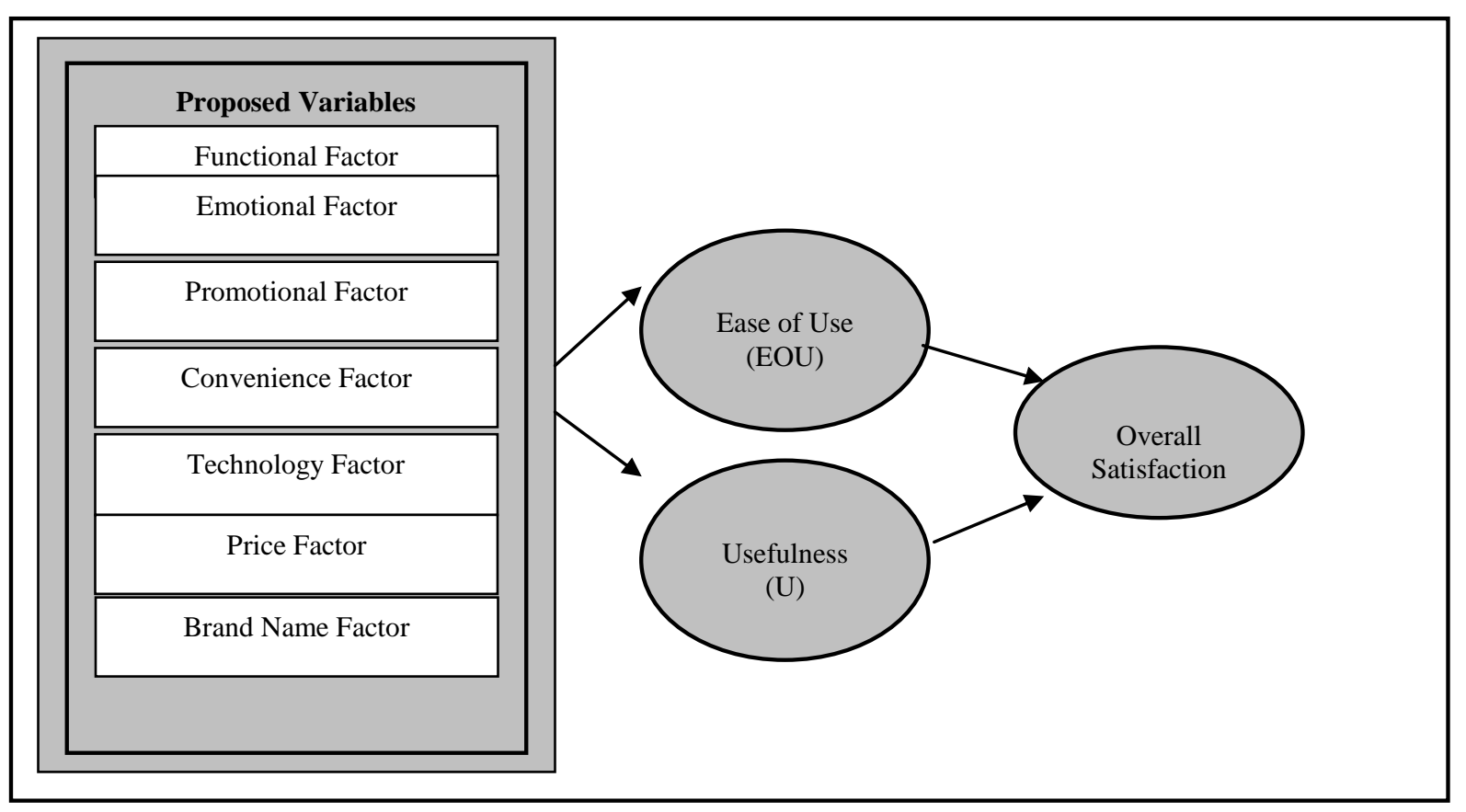

Figure 2: The Proposed Model of Users' Attitudes toward Social Networking Sites

In traditional marketplaces, emphasis is placed on customer satisfaction as a way to earn consumer loyalty and attract customers. Cho and Fjermstad (2006) examined a firm's approach to Customer Relationship Management (CRM) in order to account for the new realities of the marketplace. According to Cho and Fjermstad (2006), maximizing customer satisfaction and maintaining customer loyalty were major components of Customer Relationship Management (CRM). Satisfaction/Dissatisfaction theories, such as cognitive dissonance theory (Festinger, 1957), contrast theory (Engel \& Blackwell, 1982; Howard \& Sheth, 1969; Cardozo, 1965), AssimilationContrast Theory (Oliver, 1980), expectation-disconfirmation theory (Oliver and Desarbo, 1988), level of aspiration (LOA) theory (Yi, 1990) and adaptation level theory (Helson, 1959 and 1964) were applied in this study to measure attitudes toward social networking sites. Other theories, such as comparison-level theory, applied to explain satisfaction.

\subsection{Functional Factor}

The authors of this paper posited that, as social networking sites provided more function that allowed users to decorate their own space and allowed users to find more information, users' tendency to stick with certain sites would increase. The ways in which websites offered useful information were linked to decision-making behavior. Degeratu, Rangaswamy, and $\mathrm{Wu}(2000)$ pointed out that information availability affected consumer decision making and it differed between online and offline environments. Dick et al. (1990) also emphasized that consumers focused on relevant attributes that were available and were diagnostic when they searched for information in the online context. Web sites provide a certain degree of information and most online users are able to search for information.

Moreover, function will positively affect users' behavioral intentions to use. Cyworld.com, for example, allows users to apply various functions such as "decorating their own story room," "designing background of the homepage," "selecting various music," "using points (e.g., number of visitors, number of gifts that users sent or received) that represents the popularity of the users. In addition, Cyworld.co.kr provides integrated service to meet today users' needs by merging with mobile phone services. Therefore, this study hypothesized how users perceive the functionality that was offered by social networking sites and how that affected their perception of ease of use and usefulness. 
Hypothesis 2a: As users are more satisfied with social networking websites' functional factors, perceived ease of use will increase.

Hypothesis 2b: As users are more satisfied with social networking websites' functional factors, perceived usefulness will increase.

\subsection{Emotional Factor}

Prior studies (Danet et al. 1996) noted that computer-mediated communication (CMC) was strikingly playful. Various studies recognized the inherently playful nature of the computer as a medium (Danet et al. 1996). Previous studies (Webster \& Martocchio 1992; Gardner, Young, \& Ruth 1989) stated that playfulness was an important factor to acquaint users with the computer, by shifting attitudes from fearful and awesome aspects to positive factors. Social escapism motivation referred to consumers' motives for using the Web as a reliever of dayto-day boredom and stress (Zhou 2002: Korgaonkar \& Wolin 1999). As social networking sites provide richer and higher level of services that entertain users, this study posited that users' behavioral intention to use such sites were closely related with emotional factors. Avatars (i.e., personal icons that represent users) (Hanson 2000) and emoticons, provided by social networking sites and represent both graphical icons and text-based smileys (Huffaker \& Calvert 2005) were used to express personal feelings and characters. Dwyer (2007) addressed impression management, a key component of face-to-face interactions. According to Dwyer (2007), laughing or smiling and the way we present ourselves were all part of non-verbal cues that could strongly influence social relationships. Those entertainment factors reach families/friends, build image, express identity and enhance the quality of the life. Therefore, this study hypothesized that, as users perceive social networking sites as more entertaining, users' perceived usefulness and ease of use will increase.

Hypothesis 3a: As users are more satisfied with social networking websites' emotional/entertainment factor, users perceived ease of use will increase.

Hypothesis 3b: As users are more satisfied with social networking websites' emotional/entertainment factor, users perceived usefulness will increase.

\subsection{Promotional Factor}

Hoffman, Novak, and Chattered (1995) mentioned that e-commerce was a part of marketing on a network, which enabled and required new types of strategies and required firms to learn new ways of interacting with customers. In addition to customer interactions, e-commerce was proven as a tool to interact between users. Popular e-business sites became significant marketing tools to deliver messages through advertising, word of mouth effects, etc. For instance, Google bought the right to place search ads on MySpace pages in a multi-year, $\$ 900$ million deal, while Facebook struck a similar deal with Microsoft that was also in the hundreds of millions of dollars (Lacy 2007). Integrated promotional tools by connecting social networking usage to the mobile business are other examples how social networking sites are used as marketing tools.

Hypothesis 4a: As users are more satisfied with social networking websites' networking factor, perceived ease of use will increase.

Hypothesis 4b: As users are more satisfied with social networking websites' networking factor, perceived usefulness will increase.

\subsection{Convenience Factor}

Various researchers found that a major factor in increasing consumer satisfaction with electronic commerce was convenience (Cho et al. 2002). It is well known that a media-inherent characteristic of the Internet is its accessibility since users are able to use the Net 24 hours a day/7days a week. Online shoppers can save time on trips to stores when they place orders online. Convenience-related issues on the social networking sites include how easy 
it is to find people, ease of access, ease of making contact, and ease of making individual sites that include downloading pictures, music, decorating pages, etc. Cyworld.com is a good example of focusing on higher-level convenience by offering hybrid services to users to easily access their own space easily by connecting other media and mobile services. Therefore, this study proposes that the impact of the convenience factor on perceived usefulness and ease of use was positively associated with social networking sites.

Hypothesis 5a: As users perceive more convenience with social networking websites, users' perceived ease of use will increase.

Hypothesis 5b: As users perceive more convenience with social networking websites, users' perceived usefulness will increase.

\section{$2.5 \quad$ Technology Factor}

Prior studies discussed how perceived usefulness and ease of use were influenced by various factors, including the system's technical design characteristics (Benbasat \& Dexter 1986; Dickson, DeSanctis, \& McBride 1986; Malone 1981). Technology factors included website effectiveness, such as speed and customer interface design factors (Mohammed 2002), including content, context and customization. Technology and media-inherent factors, proposed by Schubert and Dettling (2002), were applied in this study. The extended Web Assessment Method (EWAM), proposed by Schubert and Dettling (2002), focused on the special features that are inherent in the Internet. Social networking sites developed technologies that facilitated the sharing of information through the social graph, the digital mapping of people's real-world social connections (www.facebook.com). This study selected criteria related to the technology factor from the Web Assessment Model, which was proposed by Schubert and Selz (1999), prior to EWAM. This study hypothesized that social networking site users perceived technology factors as significantly affecting their attitudes and behavior.

Hypothesis 6a: User perception of the technology factor of social networking websites is positively associated with perceived ease of use.

Hypothesis 6b: User perception of the technology factor of social networking websites is positively associated with perceived usefulness.

\subsection{Price Factor}

Users' willingness to pay played a large role in the choice and quantity of decisions (Krishnamurthi \& Raj 1988). Previous researchers stated that price was a major factor in measuring consumer sensitivity (Krishnamurthi \& Raj 1988). Price affects the perception of online users both positively and negatively. Hanson (2000) posited that the Internet could raise or lower price sensitivity among customers. Some social networking sites such as cyworld.co.kr provide option to purchase items (e.g., music, putting links to the preferred news) to decorate home pages and to make them more useful. Therefore, customers' sensitivity on price might be related to how much they dedicate to sites. Therefore, this study posited that users' willingness to pay to use services related to the social networking sites were significantly related to the perceived usefulness and ease of use. This study hypothesized that customers' perception of the price factor (i.e., willingness to pay) of social networking sites was related to the perceived usefulness and perceived easy of use.

Hypothesis 7a: As users tend to spend more on user services from social networking websites, perceived ease of use will increase.

Hypothesis 7b: As users tend to spend more on user services from social networking websites, perceived usefulness will increase. 


\subsection{Brand Name Factor}

The role of brands was frequently addressed in previous studies. Traditionally, brand names served a variety of purposes for consumers and advertisers (Meyers-Levy 1989). Meyers-Levy (1989) noted that firms with extremely memorable brand names often regarded those names as their most valuable asset because their labels provided immediate recognition and acceptance of new products that might be introduced under the brand name. This study pointed out that the role of a brand name was also significant in the online environment. Consumers $\log$ on to certain websites based on their recognition of the brand names. The role of the URL (Uniform Resource Locator), which represents the online business, is also important as online consumers recall the e-commerce sites depending on how much the URL is memorable.

Therefore, brand names could help consumers make purchase decisions in a computer-mediated environment as they enable highly reliable inferences about consumption benefits after one purchase and use (Alba et al. 1997). Keller (1993) also posited that the stronger the brand image held in the consumer memories, the more likely they will purchase those products without any additional decision making. However, as Dick et al. (1990) pointed out, brand attribute value inferences depended on the accessibility of information. This study hypothesized that brand names are an important effect on social networking sites' ease of use and usefulness.

Hypothesis 8a: User perception of the brand name factor of social networking websites is positively associated with perceived ease of use.

Hypothesis 8b: User perception of the brand name factor of social networking websites is positively associated with perceived usefulness.

\section{Methodology}

This study measured the impacts of social networking sites. Particularly, this study investigated user attitudes toward the Cyworld.co.kr, which threatened to swallow South Korea (www.businessweek.com). Various researches (Boyd and Ellison 2007; www.businessweek.com 2005) have stated that Cyworld.com which is a Web phenomenon particular to Korea was indicative of a more general blurring between the digital and physical realms. This study measured how users' attitudes and behavior toward Cyworld.com in the Korean market. The Korean market was selected because it was one of the environments where users were passionate about the social networking sites.

The study conducted a survey in Korea with approximately two hundred fifty randomly selected subjects. The survey was distributed to randomly selected audiences between June 2007 and December 2007. The response rate was about $64 \%$ and approximately $65.1 \%$ of respondents answered that they had ever used a social networking system. The data were collected from both offline and online sources. Offline survey collection was conducted via mall intercept (i.e., three selected malls in Hawaii) and randomly selected locations in Korea. The online survey was conducted via email with invitations to participate.

Operational Measures: Multi-item scales were used to measure each of the seven constructs that served as the basis for the questionnaire items. The item scales were taken from previous studies (e.g., Davis 1989; Davis, Bagozzi, \& Warshaw 1989; Bearden \& Teel 1983; Fishbein \& Ajzen 1976; Succi \& Walter 1999; Zhou 2002; Schubert \& Selz 1999; and Chen \& Wells 1999) and modified to serve the objectives of the present study. Likert scales were used to measure the items. For Likert scale questions, a seven-point scale was used with extremes labeled "Strongly Disagree" and "Strongly Agree". Quantitative methods, including factor analysis, regression, and ANOVA (Analysis of Variance), were applied to measure perceived usefulness, perceived ease of use and overall satisfaction toward social networking sites.

\footnotetext{
${ }^{1}$ Seven-point scales $(1=$ strongly disagree, 7 = strongly agree $)$ scales were employed.
} 


\section{Results}

\subsection{Respondent Demographics}

Of the two hundred fifty respondents, $61.0 \%$ were female and $39 \%$ were male. About $13.9 \%$ were between the ages of $18-20 ; 19.1 \%$ were between the ages $21-25$; $48.3 \%$ were in the $26-30$ age group; $13.4 \%$ were in the 31 35 age group; and $5.3 \%$ were age 36 or older. Approximately $8.6 \%$ reported that their highest educational level was high school graduate, while $44.0 \%$ had an associate degree, $34.9 \%$ had an undergraduate degree, and $12.4 \%$ had master's degree or higher. Approximately $21.5 \%$ were students, $1.4 \%$ were owning a business, $31.1 \%$ were business person, $3.3 \%$ were housewives, $12.4 \%$ were teachers and $8.6 \%$ were others. Approximately $58.4 \%$ had an annual average income of below $\$ 30,000,33 \%$ had an annual average income of between $\$ 30,001$ and $\$ 50,000$ and $8.6 \%$ had an annual average income of more than $\$ 50,001$. As shown in table 1 , more than $65.1 \%$ were used social networking sites more than 4 years. $29.7 \%$ of users spent between $30 \mathrm{~min}$ and 1 hour per day. $75.6 \%$ spent less than $\$ 10$ per month. Monthly average spent has measured as cyworld.com offers option to decorate their own page by purchasing online items, such as music.

\begin{tabular}{|l|l|l|l|l|l|}
\hline \# of UsageYears & Percentage & Amount of Usage Time/Day & Percentage & Monthly Average Spent & Percentage \\
\hline Less than 1 yr & $7.2 \%$ & Less than 30 min & $22 \%$ & Less than \$10 & $75.6 \%$ \\
\hline Between 1 \& 2 yrs & $8.1 \%$ & Between $30 \mathrm{~min} \& 1 \mathrm{hr}$ & $26.8 \%$ & Between $\$ 10 \& \$ 20$ & $11.0 \%$ \\
\hline Between 2 \& 4 yrs & $19.6 \%$ & Between $1 \mathrm{hr} \&$ 2hr & $29.7 \%$ & Between $\$ 20 \& \$ 30$ & $3.8 \%$ \\
\hline More than 4 yrs & $65.1 \%$ & Between $2 \mathrm{hr} \& 3 \mathrm{hr}$ & $10.5 \%$ & Between $\$ 30 \& \$ 40$ & $4.8 \%$ \\
\hline & $5.3 \%$ & More than 3hr & $11.0 \%$ & More than $\$ 40$ & $4.8 \%$ \\
\hline
\end{tabular}

Table 1: Summary of Respondents' Social Networking Site Usage

\subsection{Hypotheses Testing}

In order to check construct reliability, this study measured Cronbach's alpha for multi-item scales to measure each of the nine constructs that served as the basis for the questionnaire items. This study found that Cronbach's alpha for functional factor showed $0.73 \%$; for emotional $0.75 \%$; for promotional $0.79 \%$; for convenience, $0.81 \%$; for technology, $0.74 \%$; for price, $0.80 \%$; for brand name, $0.83 \%$.

This study conducted factor analysis to group scale items for the predictors, perceived usefulness and ease of use that affect attitudes toward social networking sites. This study ran a confirmatory factor analysis to identify those factors. Table 2 provides separate results of factor analysis for proposed variables that might affect perceived usefulness and ease of use. As shown in table 3, this study found seven factors that affect perceived usefulness and ease of use toward websites: "promotional factor," "emotional factor," "convenience factor," "functional factor," "image factor," "price factor," and "brand name factor." The results of factor analyses found that "image factor" which was considered as "emotional factor" grouped as a separate factor. Using principal components analyses as the extraction method and Varimax rotation methods with Kaiser Normalization, the most relevant data emerged. These analyses showed a distinct reduction of seven factors, with Eigen values over 1.00.

\begin{tabular}{|c|c|c|c|}
\hline \multicolumn{2}{|l|}{ Items } & \multirow[b]{2}{*}{1} & \multirow[b]{2}{*}{2} \\
\hline Factors & Scale Items & & \\
\hline EOU XI & I prefer to use a social networking website which is quite user-friendly. & .818 & \\
\hline EOU I & Overall, a social networking website is very easy to use. & .778 & \\
\hline EOU II & It is easier to access to a social networking website if it is managed by my favorite portal. & .752 & \\
\hline EOU XII & I prefer to use a social networking website which is quite easy to use. & .745 & \\
\hline EOU III & Functions from social networking website usages are easy to control. & 679 & \\
\hline EOU VIIII & Social networking website usages help make my decision easier. & .569 & \\
\hline EOU X & I often a social networking website as it is easy to contact friends, families, and business. & .526 & \\
\hline U VIII & Social networking website is useful to contact business related person. & & .895 \\
\hline U VII & Overall, social networking websites are effective. & & .836 \\
\hline U IV & Social networking website usages help make my decision easier. & & .692 \\
\hline $\mathbf{U} \mathbf{V}$ & Social networking website is useful to contact friends. & & .545 \\
\hline \multicolumn{2}{|l|}{ Eigen Value } & 6.15 & 1.20 \\
\hline
\end{tabular}

EOU: Ease of Use; U: Perceived Usefulness

Table 2: Component Matrix II 


\begin{tabular}{|c|c|c|c|c|c|c|c|c|}
\hline \multicolumn{2}{|l|}{ Items } & \multicolumn{7}{|c|}{ Components } \\
\hline Factors & Scale Items & 1 & 2 & 3 & 4 & 5 & 6 & 7 \\
\hline Promotional V & I use a social networking system more often through advertising. & .826 & & & & & & \\
\hline Promotional IV & $\begin{array}{l}\text { I like when my favorite social networking system use star as a } \\
\text { marketing tool. }\end{array}$ & .816 & & & & & & \\
\hline Promotional III & $\begin{array}{l}\text { I've used a social networking system as my favorite stars promote } \\
\text { it. }\end{array}$ & .769 & & & & & & \\
\hline Promotional VI & $\begin{array}{l}\text { The salesperson at customer service centers responded to my } \\
\text { question properly. }\end{array}$ & 694 & & & & & & \\
\hline Promotional I & I've used a social networking system as many of my friends use. & .556 & & & & & & \\
\hline Promotional II & $\begin{array}{l}\text { I feel that I am behind the trend if I don't use popular social } \\
\text { networking website. }\end{array}$ & .543 & & & & & & \\
\hline Emotional II & It is fun to use social networking website. & & .772 & & & & & \\
\hline Emotional I & I use social networking website as it gives me a pleasure. & & 672 & & & & & \\
\hline Emotional III & $\begin{array}{l}\text { Visiting my friends' home page via social networking website gives } \\
\text { me lots of fun. }\end{array}$ & & .649 & & & & & \\
\hline Emotional V & $\begin{array}{l}\text { It is my habit that I access to social networking website when I have } \\
\text { free time. }\end{array}$ & & .633 & & & & & \\
\hline Emotional VI & I often access to social networking system. & & 617 & & & & & \\
\hline Emotional IV & I often spent plenty of time with Internet. & & .570 & & & & & \\
\hline Emotional VII & $\begin{array}{l}\text { I think that social networking websites are somewhat addictive to } \\
\text { use. }\end{array}$ & & & & & & & \\
\hline Convenience II & I use social networking website as a tool to reach my friends. & & & .727 & & & & \\
\hline Convenience I & I use social networking website as a tool to reach my family. & & & .703 & & & & \\
\hline Convenience III & It is convenient to contact people via social networking system. & & & 683 & & & & \\
\hline Convenience IV & It is quite easy to contact people via social networking system. & & & 629 & & & & \\
\hline Convenience VI & $\begin{array}{l}\text { I use social networking website as I need to reach out and touch } \\
\text { someone. }\end{array}$ & & & & & & & \\
\hline Functional IV & $\begin{array}{l}\text { I am satisfied with the information obtained from a social } \\
\text { networking website (e.g., getting a title of music). }\end{array}$ & & & & .78 & & & \\
\hline Functional VI & I am satisfied when available functions are upgraded. & & & & .76 & & & \\
\hline Functional III & I often use a social networking website in order to get information. & & & & .7 & & & \\
\hline Functional V & It is wasteful if I don't use functions. & & & & .677 & & & \\
\hline Image $\mathrm{V}$ & Emoticons (e.g., minimi) represents my image. & & & & & .740 & & \\
\hline Image VII & I think that a social networking website is a tool to build my image. & & & & & .666 & & \\
\hline Image IV & $\begin{array}{l}\text { Decorations such as background, music that are used for my } \\
\text { homepage represent my image }\end{array}$ & & & & & .566 & & \\
\hline Price II & $\begin{array}{l}\text { I am willing to purchase products/services that are related to my } \\
\text { homepage. }\end{array}$ & & & & & & .821 & \\
\hline Price III & $\begin{array}{l}\text { I am willing to purchase products that are offered by a social } \\
\text { networking website as it deserves. }\end{array}$ & & & & & & .774 & \\
\hline Price I & I am willing to pay to decorate my website. & & & & & & .735 & \\
\hline Brand Name I & $\begin{array}{l}\text { I often use the most popular social networking website as it is most } \\
\text { recognized. }\end{array}$ & & & & & & & .803 \\
\hline Brand Name II & $\begin{array}{l}\text { I perceive the most well-known social networking website like a } \\
\text { well-known brand. }\end{array}$ & & & & & & & .797 \\
\hline Brand Name III & $\begin{array}{l}\text { Using popular social networking brands is quite important to } \\
\text { contact people. }\end{array}$ & & & & & & & .587 \\
\hline Eigen Value & & 15.0 & 2.93 & 1.66 & 1.53 & 1.26 & 1.13 & 1.10 \\
\hline
\end{tabular}

Table 3: Component Matrix I

This study conducted simple linear regression analyses and the analyses of variance (ANOVA). Factor scores were used for regression analyses. This study conducted regression analyses for the impacts of to perceived usefulness and ease of use. Another regression analysis was conducted to examine the effects of perceived usefulness and ease of use to the impacts of perceived usefulness and ease of use to overall satisfaction toward social networking websites. Table 4 presents the results of the regression analyses for the effects of variables to the perceived usefulness (U) and ease of use (EOU). Stepwise regression analysis was applied to determine how indicators affect perceived usefulness and ease of use. The results of regression analyses found that hypotheses $2 \mathrm{a}-$ $8 \mathrm{~b}$ were accepted except $2 \mathrm{a}, 6 \mathrm{a} \& \mathrm{~b}$, and $8 \mathrm{~b}$. As hypotheses $3 \mathrm{a} \& \mathrm{~b}$ have been divided into two, emotional and image 
factor, this study separately report results for impacts of two factors to easy of use and usefulness. The results found that both factors significantly affect easy of use and usefulness except the impact of the image factor to usefulness. The results of the analysis of variance found the models significant at the .01 level with $F=35.178$ and 18.236 (twotailed, $r$-square $=.551$ and .438 ) for perceived usefulness and ease of use.

\begin{tabular}{|l|c|c|}
\hline \multirow{2}{*}{\multicolumn{1}{c|}{ Variable }} & EOU & U \\
\cline { 2 - 3 } & $-.017(-.363)$ & $.368\left(6.673^{* *}\right)$ \\
\hline Promotional factor & $.365\left(7.726^{* *}\right)$ & $.186\left(3.378^{* *}\right)$ \\
\hline Emotional factor & $.209\left(4.421^{* *}\right)$ & $.269\left(4.885^{* *}\right)$ \\
\hline Convenience factor & $.282\left(5.967^{* *}\right)$ & $.227\left(4.114^{* *}\right)$ \\
\hline Functionality factor & $.165\left(3.479^{* *}\right)$ & $.077(1.401)$ \\
\hline Image factor & $.094\left(1.996^{*}\right)$ & $.294\left(5.331^{* *}\right)$ \\
\hline Price factor & $.507\left(10.732^{* *}\right)$ & $.041(.743)$ \\
\hline Brand Name factor & $0.05($ ) & -value) \\
\hline
\end{tabular}

** Significant at 0.01 level (2-tailed); * Significant at 0.05 level (2-tailed)

Table 4: Summary of Effects of Variables on the Perceived Easy of Use (EOU) and Perceived Usefulness (U)

Another regression analysis was conducted to investigate how overall satisfaction toward social networking sites are affected by perceived usefulness and ease of use. Table 5 shows the results of regression analysis for the impact of $U$ and EOU to the attitudes toward the websites and impact of overall satisfaction. The results of analysis of variance found that overall, the regression model was significant $(F=17.042$, significant at the .01 level, twotailed, $r$-square $=.442$ ). The study found that impact of perceived usefulness and ease of use on overall satisfaction toward the social networking sites were both significant.

\begin{tabular}{|c|c|}
\hline Predictors & Standardized Coefficient (Sig- $\boldsymbol{t}$-value) \\
\hline Perceived Ease of Use & $.321\left(4.971^{* *}\right)$ \\
\hline Perceived Usefulness & $.198\left(3.061^{* *}\right)$ \\
\hline$* *$ Significant at 0.01 level (2-tailed). &
\end{tabular}

Table 5: The Effects of Perceived Easy of Use and Usefulness on Overall Satisfaction

\section{Conclusion}

This paper is based on the premise that Internet, as an interactive computer-mediated communication (CMC) system that creates "culture" to online users and e-businesses build strategies to valued customers. Authors addressed that CMC as an intermediary is important if a customer needs more information before/after purchase and a user needs to interact with people. Authors in this paper posit that social networking sites have positioned as successful e-business examples by applying 2Is that allow users easily connect and make their own space. This study explored the impact of Social Networking Sites (SNS) which have been a significant part of e-commerce to interact and communicate between users or users and customers, such as delivering messages, sharing information, and building connections. Impacts of social networking system have been supported by various theories and models.

This research paper explored users' attitudes toward social networking sites and e-satisfaction. The findings of the study contribute to the development of the uses and gratification theory and Technology Acceptance Model, while also providing implications and suggestions for e-businesses. Applying various theories and models, this study investigated which factors affect the attitudes of online user attitudes toward social networking sites; how factors affect perceived ease of use and usefulness; and the effects of perceived ease of use and usefulness on overall satisfaction toward social networking sites. This study found important factors that affect online user attitudes toward social networking sites: a) factors such as emotional, convenience, functional, image, price and brand name factors significantly affect perceived ease of use while promotional, emotional, convenience, functional, and price 
factors; b) both perceived usefulness and ease of use significantly affect to overall satisfaction toward the social networking sites.

The author believes that more applications and usages will lead to higher user satisfaction and loyalty toward e-commerce customer relationship management (CRM). The implications of this study include the idea that to become a leader in the competitive market, e-commerce with maximized user satisfaction should have key success factors in the m-business model. The findings of the study contribute to the development of the uses and gratification theory and TAM, while also providing implications and suggestions to e-businesses.

The study has some limitations. Although this study applied multivariate statistics, such as factor and regression analysis, the study did not measure the cause and effect relationship using a program, such as LISREL. The researchers will consider this issue in future research. For future studies, researchers will also investigate user attitudes toward other social networking sites beside cyworld.co.kr. For further studies, a larger number of subjects will be surveyed.

\section{Author Information}

Dr. Yoon C. Cho is Associate Professor at the KDI School Of Public Policy And Management, global school, located in Seoul. Previously, she was Associate Professor at Hawaii Pacific University, where she served as advisor of the American Marketing Association (AMA) - HPU Chapter. She received Ph.D. from Rutgers and MBA from Cornell University. She published research papers in the various academic journals such as Advances in Consumer Research (ACR), Journal of Consumer Satisfaction, Dissatisfaction, and Complaining Behavior (JCS/DCB), Hawaii International Conference on System Sciences, Journal of Business \& Economics Research, etc. yoonji22e@gmail.com

\section{References}

1. Alba, Joseph, John Lynch, Barton Weitz, Chris Janiszewski, Richard Lutz, and Stacy Wood (1997), Interactive Home Shopping: Consumer, Retailer, and Manufacturer Incentives to Participate in Electronic Marketplaces, Journal of Marketing, (July) 61, 38-53.

2. $\quad$ Ajzen, Icek and Fishbein, Martin (1980). Understanding Attitudes and Predicting Social Behavior Englewood Cliffs, NJ, Prentice-Hall.

3. Bearden, William O. and Jesse E. Teel (1983), Selected Determinants of Consumer Satisfaction and Complaint Reports, Journal of Marketing Research, 20, February, 21-8.

4. Benbasat, I. and Dexter, A. S. (1986), An Investigation of the Effectiveness of Color and Graphical Presentation under Varying Time Constraints, MIS Quarterly, March, 59-84.

5. Boyd, Danah and Ellison, Nicole (2007), Social Network Sites: Definition, History, and Scholarship, Journal of Computer-Mediated Communication, Vol. 13, Issue 1, http://jcmc.indiana.edu/vol13/issue1/boyd.ellison.html

6. Cardozo, Richard N. (1965), An Experimental Study of Customer Effort, Expectation, and Satisfaction, Journal of Marketing Research, 2, August 244-49.

7. Chen, Qimei and Wells, William D. (1999), Attitudes Toward the Site, Journal of Advertising Research, September/October, p.27-37.

8. Cho, Y., Im, I., Hiltz, S. \& Fjermestad, J. (2002). An Analysis of Online Customer Complaints: Implications for Web Complaint Management. Proceedings of the $35^{\text {th }}$ Hawaii International Conference on System Sciences, January, Big Island, Hawaii, 176b.

9. Cho, Y. and Fjermestad J. (2006), Using eCCRM to Maximize/Minimize Customer Satisfaction/Dissatisfaction, In Electronic Customer Relationship Management, Edited by Fjermestad, J. and Romano, N.C. Jr., Advances in Management Information Systems (MIS): Special Issue on Customer Relationship Management, M.E. Sharpe, Inc., Volume 3, ISBN: 0-7656-1327-1, pp. $34-52$. 
10. Danet, Brenda, Wachenhauser, Tsameret, Bechar-Israeli, Haya, Cividalli, Amos, and Rosenbaum-Tamari, Yehudit (1996), Curtain Time 20:00 GMT: Experiments with Virtual Theater on Internet Relay Chat, Journal of Computer-Mediated Communication (JCMC), Vol. 2, No. 3, December, http://jcmc.huji.ac.il/vol2/issue3/.

11. Davis, F. D. (1989a), Perceived Usefulness, Perceived Ease of Use, and User Acceptance of Information Technology, MIS Quarterly, September, Vol.13, No.3, p.319-340.

12. Davis, F. D., Bagozzi, R. P., Warshaw, P. R. (1989b), User Acceptance of Computer Technology: A Comparison of Two Theoretical Models, in Management Science, August, Vol. 35, No. 8, p.982-1003.

13. Degeratu, A., Rangaswamy, A., \& Wu, J. (2000). Consumer Choice Behavior in Online and Traditional Supermarkets: The Effects of Brand Name, Price, and Other Search Attributes. International Journal of Research in Marketing, 17(1),55-78.

14. Dick, A., Chakravarti, D., Biehal, G. (1990), Memory-based Inferences During Consumer Choice, Journal of Consumer Research, Vol. 17, pp.82-93.

15. Dickson, G. W., DeSanctis, G. and McBride, D. J. (1986), Understanding the Effectiveness of Computer Graphics for Decision Support: A Cumulative Experimental Approach, Communication of ACM, 29, 40-47.

16. Dwyer, Catherine (2007), Digital Relationships in the 'MySpace' Generation: Results from a Qualitative Study, Proceedings of the 40th Hawaii International Conference on System Sciences (HICSS), 2007.

17. Engel, J. F. and Blackwell, R. D. (1982). Consumer Behavior (4 ${ }^{\text {th }}$ ed.). New York, Holt, Rinehart and Winston.

18. Gardner, E. P., Young, P., and Ruth, S. R. (1989), Evolution of Attitudes Toward Computers: A Retrospective Review, Behavior and Information Technology, Vol.8, Issue 2, p. 89-98.

19. Festinger, L. (1957). A Theory of Cognitive Dissonance. Stanford, California: Stanford University Press.

20. Fishbein, M. and Ajzen, Icek (1976), Belief, Attitude, Intention, and Behavior: An Introduction to Theory and Research, Reading, MA: Addison-Wesley.

21. Gardner, E. P., Young, P., and Ruth, S. R. (1989), Evolution of Attitudes Toward Computers: A Retrospective Review, Behavior and Information Technology, Vol.8, Issue 2, p. 89-98.

22. Garton, L., Haytornthwaite, C., and Wellman, B. (1997), Studying Online Social Networks, JCMC, 3, 1, http://www.ascusc.org/jcmc/vol3/issue1/garton.html

23. Hagel, John and Armstron, Arthur (1997), Net Gain: Expanding Markets Through Virtual Communities, HBS Press, Cambridge.

24. Hanson, Ward (2000), Principles of Internet Marketing, South-Western College Publishing.

25. Helson, H. (1959) Adaptation-Level Theory in Psychology: A Study of a Science, 1, Sigmund Koch, (eds.), New York: McGraw-Hill.

26. Helson H. (1964), H. Adaptation-Level Theory, New York: Harper \& Row.

27. Howard, J. A. and Sheth, J. N (1969). The Theory of Buyer Behavior. New York, John Wiley and Sons.

28. Huffaker, D. A. and Calvert, S.L. (2005), Gender, Identity, and Language Use in Teenage Blogs, Journal of Computer-Mediated Communication, 10 (2), February, http://jcmc.indiana.edu/vol10/issue2/huffaker.html

29. Hemp Paul (2006), Avatar-Based Marketing, Harvard Business Review, June.

30. Herzog, H. What Do We Really Know About Day-Time Serial Listeners?: Radio Research. Paul F. Lazarsfeld and Frank N. Stanton, (eds.), New York: Duel, Sloan and Pearce, (1944).

31. Hoffman, Donna L. and Novak, Thomas P., and Chatterjee, Patrali (1995), Commercial Scenarios for the Web: Opportunities and Challenges, Journal of Computer-Mediated Communication, JCMC, Special Issue on Electronic Commerce, 1, 3, http://www.ascusc.org/jcmc/vol1/issue3/hoffman.html.

32. Keller, K. L. (1993), Conceptualizing, Measuring, and Managing Customer-Based Brand Equity, Journal of Marketing, Vol. 57, Issues 1.

33. Korgaonkar, Pradeep K. and Wolin, Lori D. (1999), A Multivariate Analysis of Web Usage, Journal of Advertising Research, March/April, 53-68.

34. Krishnamurthi, Lakshman and Raj, S. P. (1988), A Model of Brand Choice and Purchase Quantity Price Sensitivities, Marketing Science, Vol. 7, No. 1, Winter, 1-20.

35. Lacy, Sarah (2007), What MySpace-Facebook Rivaly? Business Week Online, pp.1-2.

36. Luo, X. Uses and Gratifications Theory and E-Consumer Behaviors: A Structural Equation Modeling Study. Journal of Interactive Advertising, 2, 2 Spring, (2002). 
37. Malone, T. W. (1981), Toward a Theory of Intrinsically Motivating Instruction, Cognitive Science, 4, 333369.

38. Mcguire, W. J. (1974), Psychological Motives and Communication Gratification: The Uses of Mass Communications. Jay G. Blumler and Elihu Katz, eds., Beverly Hills, CA: Sage Publications.

39. Meyers-Levy, J. (1989), The Influence of a Brand Name's Association Set Size and Word Frequency on Brand. Memory, Journal of Consumer Research, 16, September, 197-207.

40. Mohammed, Rafi. A., Fisher, Robert J., Jaworski, Bernard J., and Cahill, Aileen M. (2004), Internet Marketing: Building Advantage in a Networked Economy, McGraw-Hill Irwin, Marketspace U.

41. Oliver, R. L. A Cognitive Model of the Antecedents and Consequences of Satisfaction Decisions. Journal of Marketing Research, 17, (1980), 460-69.

42. Oliver, R. L. and DeSarbo, W. S. (1988). Response Determinants in Satisfaction Judgments. Journal of Business Research, 14, March, 495-507.

43. Schubert, Petra and Dettling, Walter (2002), Extended Web Assessment Method (EWAM): Evaluation of E-Commerce Applications from the Customers' Viewpoint, Proceedings of the $35^{\text {th }}$ Hawaii International Conference on System Sciences, Hawaii.

44. Schubert, Petra and Dorian Selz (1999), Web Assessment: Measuring the Effectiveness of Electronic Commerce Sites Going Beyond Traditional Marketing Paradigms, Proceedings of the $32^{\text {nd }}$ Hawaii International Conference on System Sciences.

45. Succi, M. J. and Walter, Z. D. (1999). Theory of User Acceptance of Information Technologies: An Examination of Health Care Professionals. Proceedings of the $32^{\text {nd }}$ Hawaii International Conference on System Sciences, Hawaii, 4013.

46. Yi, Y. (1990) A Critical Review of Consumer Satisfaction. Review of Marketing, Valerie A. Zeithaml, (eds.), Chicago, American Marketing Association.

47. Webster, Jane and Martocchio, Joseph J. (1992), Microcomputer Playfulness: Development of a Measure With Workplace Implications, MIS Quarterly, June, p.201-226.

48. Zhou, Zheng (2002), Users' Attitudes Toward Web Advertising: Effects of Internet Motivation and Internet Ability, Advances in Consumer Research, Vol. 29, p. 71-78.

\section{Online Resources:}

www.rheingold.com

www.comscoreMediaMetrix.com

www.en.wikepedia.org

www.businesweek.com

www.facebook.com 
NOTES 